\title{
Improving 0phthalmic Tear Replacement Therapies: A Bioengineering Approach: Mini Review
}

\author{
David Williams* \\ Department of Veterinary Medicine, University of Cambridge, UK
}

Submission: February 27, 2017; Published: March 21, 2017

*Corresponding author: David Williams, Department of Veterinary Medicine, University of Cambridge, The Old Schools, Trinity Ln, Cambridge CB2 1TN, UK, Email: dlw33@cam.ac.uk

\section{Introduction}

Dry eye is a troubling and widespread condition affecting between 5 and $35 \%$ of humans globally [1,2] and between 0.5 and $35 \%$ of dogs [3]. Topical cyclosporine or tacrolimus, used as lacrimogenic agents, have improved the treatment of dry eye in people and animals substantially $[3,4]$ but topical tear improvement and replacement still plays an important role in the alleviation of the pathological changes and ocular signs and symptoms seen in cases of dry eye. The problem with such topical lacrimomimetic therapy is the frequency with which tear replacement drops still have to be applied resulting in poor compliance by human patients or owners of affected dogs [5]. Topical therapies range from those such as Lacri-lube containing lanolin derived from the sebaceous glands of wool-bearing animals such as sheep and comprised predominantly of long chain waxy esters, through carboxy methylcellulose or hydroxy propylmethyl cellulose (HPMC) [6] through polyvinyl alcohol (PVA) [7] to carbomer-based medications and hyaluronic acid (HA) in various formulations [8-10]. We have recently shown a cross-linked HA polymer hydrogel to have significantly better efficacy than regular HA in a spontaneous canine model of dry eye both in an open-label [11] (Figure 1)and masked controlled study [12]. Here the structure and function of the tear film is discussed together with the development and beneficial effects of this novel topical liquid-gel formulation.

\section{The Normal Tear Film}

Developing an optimised tear replacement therapy requires a knowledge of the normal tear film. Previously the tear film was presumed to be comprised of three layers, an inner mucin layer, a middle aqueous layer and an outer lipid layer. More recently studies have shown that such a simple trilaminar structure is not fully representative of the tear film. There are mucins which are attached to the outer surface of the corneal epithelium and mucins which are free in the tear film so the boundary between the mucin layer and aqueous layer is much more complex than previously thought. Epithelial cells of the ocular surface produce high molecular weight heavily glycosylated membrane-bound mucins (MUC1, MUC4, and MUC16) which form a hydrophilic barrier, the glycocalyx, key in lubrication and protection of the eye [13]. Mucins are not only attached to the ocular surface but secretory mucins MUC7 and the gel-forming MUC5AC are also liberated into the tear film [14]. The glycosylation of the mucins allows the glycocalyx to reduce friction during blinking and enables the tearfilmto maintain wetting of the eye and stay in place. The outer lipid layer originates predominantly from the Meibomian glands which empty their products at the lid margin. This tear film lipid layer only comprises $0.3 \%$ of the tear film but it is a highly complex mix of lipids vital in spread and stabilization of the tear film [15].

With the eye open, the tear film needs to have a high viscosity to resist tear film breakup. But during blinking the tear film must be of a low viscosity to avoid damage to the epithelial cells of the ocular surface [16]. As the tear film flows therefore, it exhibits non-Newtonian rheology with so-called shear-thinning where the viscosity falls as the shear rate increases. The problem is that while the mix of mucins, lipids and aqueous secretion allows such a complex flow behavior, modeling this in an artificial tear replacement is difficult. Tear fluid with its lipid component removed exhibits Newtonian flow characteristics and it is only with the reconstitution of lipids that the non-Newtonian nature is restored [14]. This does not depend on the lipid bilayer on the tear film surface nor in free lipids within the tear film however, but rather the protein tear lipocalin (TL) with its ability to bind hydrophobic lipids [17]. Apo-TL shows classic shear-thinning behavior with a viscosity reaching $18 \mathrm{mPa}$ s at its lowest shear rate reducing to $0.92 \mathrm{mPa} s$ at its highest shear rate of $130 \mathrm{~s}-1$.

\section{Rheology of tear replacements}

Long chain molecules in which there are high levels of intra molecular interactions give flow characteristics more similar to those of the normal tear film than simple small molecule topical medications [18]. Carbomers are polyacrylic acid polymers, available as linear, branched or cross-linked molecules with the acidic carboxyl groups partially dissociating in water to produce 
a flexible coil. Different molecules behave in varying manners with those having long alkyl chains acting more elastically and those with shorter ones being less elastic, these having different muco adhesive indices [19-21]. Older tear replacement eye drops such as those based on carboxy methyl cellulose, polyvinyl alcohol have the disadvantage that, although they are long-chain molecules, there is limited inter-chain interaction. Carbomers can be covalently cross-linked substantially changing their rheological properties [19] and cross-linked hyaluronic acid gels have been used as agents for tissue reconstruction, drug delivery, more recently as very safe and effective tear substitutes $[22,23]$ (Figure 1).

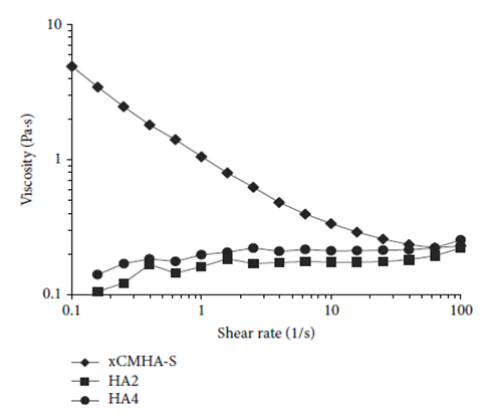

Figure 1: Markedly reduced viscosity of the cross-linked HA product at high sheer rates shows non-Newtonian flow dynamics reproduced.

\section{Development of a novel cross-linked hyaluronic acid} hydrogel, CMHA-S

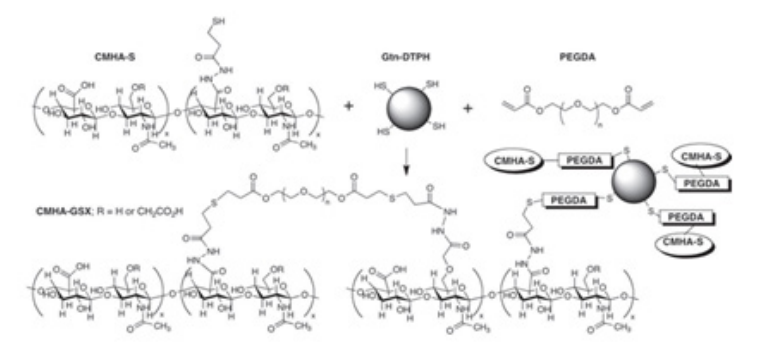

Figure 2:The chemistry behind formation of a cross-linked hyaluronic acid polymer acting as a tear replacement and corneal repair gel.

Researchers at the University of Utah developed a new disulphide cross-linking technique which allowed them to prepare a hyaluronic acid hydrogel from thiolated hyaluoronic acid by synthesing dithiobis propanoic dihydrazide and diothiobidbutyric dihydrazide and coupling them to hyaluronic acid through a carbodiimide intermediate giving the compound shown in Figure 2, reducing the disulphide bonds thus formed using dithioreitol and purifying with exhaustive dialysis [22,23]. This cross linked thiolated carboxy methylated hyaluronic acid is referred to as CMHA-S. Differential oxidation can modify the degree of disulphide cross-linking and thus the viscosity of the gel [22].Rheological studies show the CMHA-S to behave in nonNewtonian manner as shown in the graph of shear rate and viscosity in figure 2 where the viscosity reduces dramatically with increasing shear rate. Previous work has shown that the CMHA-S accelerated healing and re-epithelization of experimentally induced corneal ulcers [24] and recent work has extended this work showing similar effects in spontaneous ulceration of canine and feline corneas [25]. As noted above we showed the CMHA-S to have great benefits in cases of dry eye in canine patients in our hospital $[11,12]$. The CMHA-S has great potential for use in cases of dry eye and those with corneal ulceration both in both domestic pet species and in human patients, where a tremendous unmet need exists. CMHA-S has recently demonstrated positive data in clinical studies for accelerating corneal epithelial defect closure post refractive surgery in humans, again confirming the safety and effectiveness of this product.

\section{Conclusion}

While the tear film may seem a simple structure, it is in effect a highly complex molecular mix behaving such that it is retained on the ocular surface with a relatively high viscosity, but once moved by the eyelid margin during blinking has a low viscosity. Emulating this non-Newtonian fluid behaviour in artificial tear formations is a difficult task, but recent advances with crosslinked hyaluronic acid moieties, such as the CMHA-S, have made significant advances in optimizing tear replacement therapies which can have a benefit in protecting and re-epithelizing an injured cornea.

\section{References}

1. Janine AS (2007) The epidemiology of dry eye disease: report of the epidemiological subcommittee of the international dry eye workshop. Ocul Surf 5(2): 93-107.

2. Brewitt H, Sistani F (2001) Dry eye disease: the scale of the problem. Surv Ophthalmol 45 (Suppl 2): S199-S202.

3. Williams DL (2008) Immunopathogenesis of References keratoconjunctivitis sicca in the dog. Vet Clin North Am Small Anim Pract 38(2): 251-68.

4. Hendrix DV, Adkins EA, Ward DA, Stuffle J, Skorobohach B (2011) An investigation comparing the efficacy of topical ocular application of tacrolimus and cyclosporine in dogs. Vet Med Int 2011: 487-592.

5. Swanson M (1998) Compliance with and typical usage of artificial tears in dry eye conditions. J Am Optom Assoc 69(10): 649-655.

6. Bruix A, Adán A, Casaroli-Marano RP (2006) Efficacy of sodium carboxymethylcellulose in the treatment of dry eye syndrome. Arch Soc Esp Oftalmo 81(2): 85-92.

7. Snibson GR, Greaves JL, Soper ND, Tiffany JM, Wilson CG, et al. Ocular surface residence times of artificial tear solutions. Cornea 11(4): 288293.

8. Williams D, Middleton S, Fattahian H, Moridpour R (2012) Comparison of hyaluronic acid-containing topical eye drops with carbomer-based topical ocular gel as a tear replacement in canine keratoconjunctivitis sicca: A prospective study in twenty five dogs. Vet Res Forum 3(4): 229-232. 
9. López-de la Rosa A, Pinto-Fraga J, Blázquez Arauzo F, Urbano Rodríguez R, González-García MJ (2016) Safety and Efficacy of an Artificial Tear Containing 0.3\% Hyaluronic Acid in the Management of Moderate-toSevere Dry Eye Disease. Eye Contact Lens 2016 May 26. [Epub ahead of print].

10. Pinto-Fraga J, López-de la Rosa A, Blázquez Arauzo F, Urbano Rodríguez R, González-García MJ (2017) Efficacy and Safety of 0.2\% Hyaluronic Acid in the Management of Dry Eye Disease. Eye Contact Lens 43(1): 57-63.

11. Williams DL, Mann BK (2013) A Crosslinked HA-Based Hydroge Ameliorates Dry Eye Symptoms in Dogs. Int J Biomater 2013: 460437

12. Williams DL, Mann BK (2014) Efficacy of a crosslinked hyaluronic acid-based hydrogel as a tear film supplement: a masked controlled study. PLoS One 9(6): e99766.

13. Ablamowicz AF, Nichols JJ (2016) Ocular Surface Membrane-Associated Mucins. Ocul Surf 4(3): 331-341.

14. Tiffany JM (1991) The viscosity of human tears. International Ophthalmology 15(6): 371-376.

15. Cwiklik L (2016) Tearfilm lipid layer: A molecular level view. Biochim Biophys Acta 1858(10): 2421-2430.

16. Zhang YL, Matar OK, Craster RV (2003) Analysis of tearfilm rupture: effect of non-Newtonian rheology. J Colloid Interface Sci 262(1): 130148.

17. Dartt DA (2011) Tear lipocalin: structure and function. Ocul Surf 9(3): 126-138.

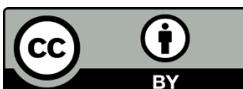

his work is licensed under Creative

Commons Attribution 4.0 Licens

DOI: 10.19080/CTBEB.2016.01.555589
18. Bhamla MS, Chai C, Rabiah NI, Frostad JM, Fuller GG (2016) Instability and Breakup of Model Tear Films. Invest Ophthalmol Vis Sci 57(3): 949-958.

19. Ceulemans J, Ludwig A (2002) Optimisation of carbomer viscous eye drops: an in vitro experimental design approach using rheological techniques. Eur J Pharm Biopharm 54(1): 41-50.

20. Bother $\mathrm{H}$, Waaler $\mathrm{T}$ (1990) Rheological characterization of tear substitutes. Drug Dev Ind Pharm 16(5): 755-768.

21. Tiffany JM (1994) Viscoelastic properties of human tears and polymer solutions. Adv Exp Med Biol 350: 267-270.

22. Zheng Shu X, Liu Y, Palumbo FS, Luo Y, Prestwich GD (2004) In situ crosslinkable hyaluronan hydrogels for tissue engineering. Biomaterials 25(7-8): 1339-1348.

23. Wirostko B, Mann BK, Williams DL, Prestwich GD (2014) Ophthalmic Uses of a Thiol-Modified Hyaluronan-Based Hydrogel. Adv Wound Care (New Rochelle) 3(11): 708-716.

24. Yang G, Espandar L, Mamalis N, Prestwich GD (2010) A cross-linked hyaluronan gel accelerates healing of corneal epithelial abrasion and alkali burn injuries in rabbits. Vet Ophthalmol 13(3): 144-150.

25. Williams DL, Wirostko BM, Gum GG, Mann BK (2017) Topical cross linked HA-based hydrogel acceleratesclosure of corneal epithelial defects and repair of stromalulceration in companion animals. Inv Ophth Vis Sci 2017, in review.

\section{Your next submission with Juniper Publishers} will reach you the below assets

- Quality Editorial service

- Swift Peer Review

- Reprints availability

- E-prints Service

- Manuscript Podcast for convenient understanding

- Global attainment for your research

- Manuscript accessibility in different formats ( Pdf, E-pub, Full Text, Audio)

- Unceasing customer service

Track the below URL for one-step submission https://juniperpublishers.com/online-submission.php 